\title{
Montmorillonite clay-modified disposable ink-jet-printed graphene electrode as a sensitive voltammetric sensor for the determination of cadmium(II) and lead(II)
}

\author{
Léopoldine S. Guenang ${ }^{1,2,3}$ - Liliane M. Dongmo ${ }^{1}$. Sherman L. Z. Jiokeng ${ }^{1} \cdot$ Arnaud T. Kamdem $^{4}$. \\ Giscard Doungmo ${ }^{1,5} \cdot$ Ignas K. Tonlé ${ }^{\prime} \cdot$ Victor Costa Bassetto ${ }^{3} \cdot$ Milica Jović $^{3} \cdot$ Andreas Lesch $^{6} \cdot$ Hubert Girault $^{3}$
}

Received: 22 October 2019 / Accepted: 17 February 2020 / Published online: 24 February 2020

(c) Springer Nature Switzerland AG 2020

\begin{abstract}
This work describes a new sensitive sensor for the simultaneous electrochemical determination by square wave anodic stripping voltammetry of $\mathrm{Cd}^{2+}$ and $\mathrm{Pb}^{2+}$ ions in aqueous solution, based on a disposable ink-jet-printed graphene electrode (IPGE) modified by a thin film of montmorillonite (Mont) clay mineral. The clay was characterized by X-ray diffraction and scanning electron microscopy while the Mont-IPGE was analyzed by electrochemical impedance spectroscopy (EIS) and cyclic voltammetry before its exploitation for sensing studies. EIS results revealed a low electron transfer rate on Mont-IPGE during the electro-oxidation of $\left[\mathrm{Fe}(\mathrm{CN})_{6}\right]^{3-}$. The stripping response on both $\mathrm{Cd}^{2+}$ and $\mathrm{Pb}^{2+}$ analytes was improved by the in situ co-deposition with bismuth, added to the electrolyte solution, on the clay substrate. The proposed electrode showed great stability and good reproducibility. The key experimental parameters governing the stripping analysis of $\mathrm{Cd}^{2+}$ and $\mathrm{Pb}^{2+}$ were optimized. A linear relationship between peak currents and concentrations of the analytes was obtained in the range from 0.01 to $0.21 \mu \mathrm{M}$, leading to detection limits of $0.42 \mathrm{nM}$ for $\mathrm{Cd}^{2+}$ and $1.14 \mathrm{nM}^{-2} \mathrm{~Pb}^{2+}$ ions, respectively $(\mathrm{S} / \mathrm{N}=3)$. The sensitivities to $\mathrm{Cd}^{2+}$ and $\mathrm{Pb}^{2+}$ ions were $921.8 \mathrm{~A} \mathrm{~cm}^{-2} \mathrm{M}^{-1}$ and $1960.8 \mathrm{~A} \mathrm{~cm}^{-2} \mathrm{M}^{-1}$, respectively. The Mont-IPGE sensor was used for the quantification of lead and cadmium in a mineral water.
\end{abstract}

Keywords Disposable ink-jet-printed graphene electrode $\cdot$ Montmorillonite $\cdot$ Cadmium(II) $\cdot$ Lead(II) $\cdot$ Bismuth(III) . Square wave voltammetry

\section{Introduction}

Heavy metals are pollutants that represent a growing environmental problem that can affect various components of the environment [1]. The presence of heavy metals in water has caused serious damage to the human immune system due to bioaccumulation in various ecosystems [2, 3]. Lead and cadmium are among the most toxic heavy metals, and the World Health Organization guidelines set their acceptable threshold concentration in drinking water of less than 10 and $3 \mu \mathrm{g} / \mathrm{L}$, respectively [4]. For the monitoring and the detection of heavy metals, several techniques are commonly used, such as atomic absorption spectrometry [5], atomic fluorescence spectrometry [6], ion chromatography [7] and inductively coupled plasma mass spectrometry [8]. Despite their importance, these methods have some disadvantages, such as the time and high costs they require, the need for complex

$\triangle$ Ignas K. Tonlé, itonle@yahoo.com | 1 Electrochemistry and Chemistry of Materials, Department of Chemistry, University of Dschang, Dschang, Cameroon. ${ }^{2}$ Inorganic Chemistry Laboratory, Department of Chemistry, University of Buea, Buea, Cameroon. ${ }^{3}$ Laboratoire d'Electrochimie Physique Et Analytique, EPFL, Station 6, 1015 Lausanne, Switzerland. ${ }^{4}$ Freiburg Materials Research Center (FMF), University of Freiburg, Stefan Meier Strasse 21, 79104 Freiburg, Germany. ${ }^{5}$ Institute of Inorganic Chemistry, Christian-Albrechts-Universität zu Kiel, Max-Eyth-Straße 2, 24118 Kiel, Germany. ${ }^{6}$ Department of Industrial Chemistry “Toso Montanari”, University of Bologna, Viale del Risorgimento 4, 40136 Bologna, Italy. 
instruments and the difficulty of field analysis. Besides, the development of new and sensitive methods remains for the quantification at trace levels for this class of pollutants remains a daily necessity. To meet these requirements, electrochemical methods offer several advantages such as simplicity, accuracy, low cost, remarkable sensitivity, high stability and the ability to determine several analytes in the same matrix. In these lines, anodic stripping voltammetry (ASV) has been widely recognized as a powerful technique for the determination of trace metal ions through two experimental steps: the preconcentration of analytes followed by their electrochemical stripping measurements [9]. The choice of the working electrode is decisive for the success of the stripping operation [10]. Electrodes chemically modified using a convenient material have been shown to display higher selectivity due to the ability of the modifier to capture specific metal ions [11]. They are usually made up of a conductive material that is coated with a molecular, ionic or polymeric film or an inorganic material able to capture a target analyte [12]. Thus, chemically modified electrodes (CMEs) represent one of the main areas of electrochemistry research with many applications including analytical chemistry $[13,14]$, solar energy conversion $[15,16]$, electrochromic display devices [17] and molecular electronic devices [18]. In the analytical field, different types of conductive materials were used to develop CMEs: polymers [19, 20], mesoporous silicate films [21, 22], nanoparticles [23] and clay minerals [9, 24-27]. Clay-modified electrodes have distinct advantages over conventional electrodes in many areas of application, such as electrocatalysis, electrochemical sensors and preconcentration electroanalysis. These electrodes have the advantage of being naturally attractive for the electrochemical detection of environmental pollutants [28-31]. For their development, different modification techniques are used to increase the sensitivity of electrochemical sensors. They include drop casting, spin coating and drop coating $[9,24,25]$. Montmorillonite is a natural and inexpensive clay material found in many parts of the world and composed of layers of silicates stacked on top of each other. Its physical and chemical properties are attributed to its large surface area and multilayer structure [32]. It has already been used to modify solid substrates such as glassy carbon electrodes [33,34] or carbon paste electrodes $[35,36]$. On the other hand, screen-printed electrodes have been exploited to address measurements in the field using portable devices with low-cost disposable electroanalytical sensors [37]. Ink-jet printing as an alternative material deposition technique has become of interest in particular due to the versatility in sensor designing and production thanks to the digitally controlled noncontact deposition of a large range of material containing inks. In drop-on-demand ink-jet printers, ink droplets are generated on demand leading to minimum ink waste. This offers in particular for expensive and rare materials a big advantage over screen printing where a large amount of ink remains on the screens. In the field of electroanalytical sciences devoted to ink-jet printing technology for amperometric sensors, some pertinent works have been published: Dong et al. used an ink-jet-printed ionic liquid-carbon nanotube-graphene film electrode for the detection of heavy metals in water samples [38]. Lesch et al. [39] prepared on large-scale ink-jet-printed carbon nanotubes electrodes for the detection of antioxidants in blood bags. In terms of the working electrode material, graphene (GN) and its derivatives are nowadays intensively investigated. The resort to $\mathrm{GN}$ is due to its 2D structure, in which $\mathrm{sp}^{2}$ carbon atoms are arranged in a honeycomb network. GN has a lower resistance to charge transfer, a high surface area and a strong mechanical stability [40-42]. In connection with electrochemistry, a larger electrochemical potential window was reported [43].

For the detection of heavy metal ions, some recently reported works include the combination of $\mathrm{GN}$ or graphene oxide with piperazine [44], carboimidazole [45], $\mathrm{CO}_{3} \mathrm{O}_{4}$ nanoparticles [46] and PEDOT nanorods [47]. One could also mention a recent review by Zuo et al. [48] which summarizes the progress made in the past few years in the field of sensors dedicated to heavy metal ions, based on GN-derived materials.

Herein, the modification of an ink-jet-printed, disposable graphene electrode with a swelling-type clay mineral, i.e., montmorillonite clay, was addressed for the first time. The ink-jet-printed electrode was modified by drop casting and exploited for the simultaneous detection of trace amounts of $\mathrm{Cd}^{2+}$ and $\mathrm{Pb}^{2+}$ ions using square wave anodic stripping voltammetry (SWASV). The experimental conditions were carefully investigated and optimized. Furthermore, the clay-coated graphene electrode was applied for the determination of cadmium and lead in a mineral water sample.

\section{Experimental section}

\subsection{Clay mineral, reagents and apparatus}

A Na-rich montmorillonite from Crook County, Wyoming (SWy-2), with a cationic exchange capacity (CEC) of $85 \mathrm{meq} / 100 \mathrm{~g}$ was received from the source clay minerals repository of the Clay Minerals Society, Purdue University, West Lafayette (USA). The clay fraction with particle size less than $2 \mu \mathrm{m}$ was used to prepare the dispersion employed for the modification of the IPGE. This fraction was collected by wet sedimentation according to previously published procedures $[33,34]$. Cadmium(II) nitrate 
$\left(\mathrm{Cd}\left(\mathrm{NO}_{3}\right)_{2}\right)$ and lead(II) nitrate $\left(\mathrm{Pb}\left(\mathrm{NO}_{3}\right)_{2}\right)$ salts were obtained from Sigma-Aldrich, and a standard solution of $0.01 \mathrm{M}$ was prepared. Millimolar solutions of bismuth nitrate pentahydrate $\left(\mathrm{Bi}\left(\mathrm{NO}_{3}\right)_{3} \cdot 5 \mathrm{H}_{2} \mathrm{O}, 99.99 \%\right)$ were prepared by diluting a $0.1 \mathrm{M}$ stock solution. Acetate buffer solution ( $\mathrm{ABS}, \mathrm{pH}$ 4.5) was prepared by mixing appropriate amounts of $0.1 \mathrm{M} \mathrm{CH}_{3} \mathrm{COONa}$ and $0.1 \mathrm{M} \mathrm{CH}_{3} \mathrm{COOH}$. All solutions were prepared with purified water. The morphology of Mont-coated ink-jet-printed GN electrodes was investigated by scanning electron microscopy (SEM) using an Amray 1610 Turbo SEM. The samples were coated with gold under vacuum using a sputter coater. $X$-ray diffraction analysis was performed using a Stoe Stadi-p X-ray powder diffractometer (Stoe \& Cie GmbH, Darmstadt, Germany), operating with a $\mathrm{Cu}$ Ka1 radiation $\left(\lambda_{\mathrm{Cu}}=1.54056 \AA\right)$ at $40 \mathrm{kV}$ and $30 \mathrm{~mA}$. The $\mathrm{pH}$ of the solutions was measured or adjusted using a Mettler Toledo $\mathrm{pH}$ meter. The morphology of the IPGE and Mont-IPGE was investigated using scanning electron microscopy [Dual Beam TM 3D FEG; FEl; CES-Ruhr Universität Bochum (Germany)] equipped with an energy-dispersive X-ray detector (EDAX Genesis XM2i; EDAX) operating at $20 \mathrm{kV}$.

\subsection{Preparation of ink-jet-printed disposable graphene electrodes}

Two ink-jet printing platforms were used in this work to fabricate thin-film graphene electrodes. The DMP-2850 printer from Fujifilm Dimatix was employed to deposit two ink-jet-printed layers of graphene dispersion (graphene ink for ink-jet printing with ethyl cellulose in cyclohexanone and terpineol, Sigma-Aldrich). The X-Serie Ceraprinter from Ceradrop was used to simultaneously print and photopolymerize with an integrated UV LED (FireEdge FE300 380-420 nm; Phoseon Technology) and a UV-curable dielectric ink (EMD 6200 from SunChemical) as insulating material in order to define accurately the electrode area and to insulate partially the graphene patterns that were used as electronic traces. Disposable Dimatix DMC-11610 cartridges containing 16 individually addressable nozzles and generating nominally $10 \mathrm{pL}$ droplets were used in both machines for both inks. All printing parameters, such as the voltage pulse for the piezoelectric actuation inside the nozzles, jetting frequency, droplet falling speed, overlapping distance of adjacent droplets and substrate temperature, were optimized for each printed layer. After the printing of the graphene ink, the patterns were thermally cured for $1 \mathrm{~h}$ in a furnace at $400{ }^{\circ} \mathrm{C}$. The insulation layer was deposited as a frame around the graphene pattern to create a squared working electrode area of theoretically $1 \mathrm{~mm}^{2}$ (Fig. 1). The elaborated ink-jet-printed disposable graphene electrode is herein referred to as IPGE.

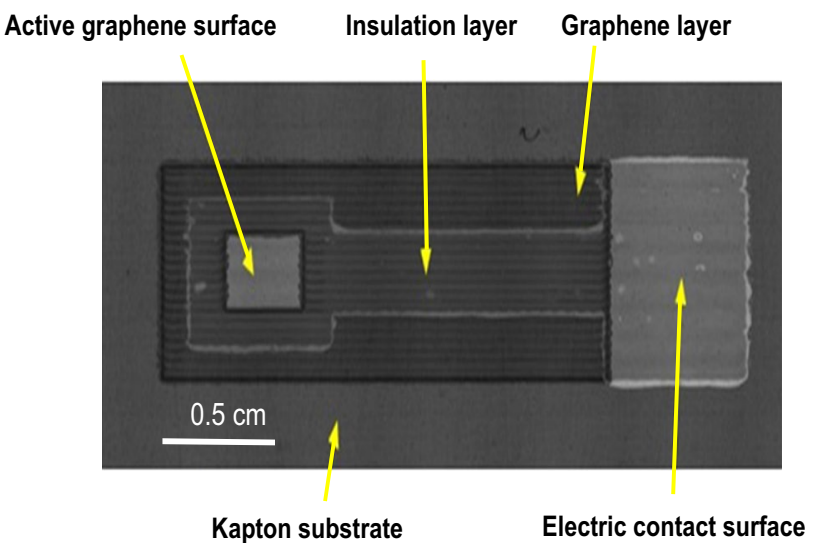

Fig. 1 A black-white photograph of an ink-jet-printed disposable graphene electrode (IPGE), taken with the sample observer camera of the CeraPrinter

\subsection{Modification of the IPGE}

The thin-film clay-modified IPGE was prepared as follows: $3 \mathrm{mg}$ of Mont (particle size $\leq 2 \mu \mathrm{m}$ ) was dispersed in $1 \mathrm{~mL}$ of purified water and shaken for $2 \mathrm{~min}$. Thereafter, $0.5 \mu \mathrm{L}$ of the dispersion was drop-casted on the IPGE and dried at $100^{\circ} \mathrm{C}$ for $5 \mathrm{~min}$. Throughout the text, the modified electrodes are referred to as Mont-IPGE for the ink-jetprinted graphene electrode modified by a film of purified montmorillonite.

\subsection{Electrochemical procedures}

Electrochemical impedance spectroscopy (EIS), cyclic voltammetry (CV) and square wave voltammetry (SWV) were performed on a Palmsens ${ }^{3}$ potentiostat using the PS Trace 4.2 electrochemical analysis software. The CVs were recorded under quiescent conditions immediately after the immersion of the working electrode in a conventional single compartment cell containing the "analyte + electrolyte" solution, a pseudo-reference electrode $\left(\mathrm{Ag} / \mathrm{Ag}^{+}\right)$ and a platinum wire auxiliary electrode. SWV measurements were performed in an electrochemical cell containing $50 \mathrm{~mL}$ of $0.1 \mathrm{M} \mathrm{ABS}(\mathrm{pH} 4.5)$ and $2 \mu \mathrm{M} \mathrm{Bi}^{3+}$, filled with known amounts of $\mathrm{Cd}^{2+}$ and $\mathrm{Pb}^{2+}$ ions. The preconcentration step (also known as accumulation) was carried out at $-1 \mathrm{~V}$ for $180 \mathrm{~s}$ under stirring. During this step, $\mathrm{Bi}^{3+}$ ions and the target metals were simultaneously deposited on the surface of the electrode. After the accumulation time, the stirring was stopped and the SWV curves were recorded from $-1.5 \mathrm{~V}$ to $0.0 \mathrm{~V}$ by applying the following parameters: frequency $25 \mathrm{~Hz}$; potential step increments $10 \mathrm{mV}$; and potential amplitude $25 \mathrm{mV}$. All experiments were conducted at room temperature. EIS measurements were carried out in $0.1 \mathrm{M} \mathrm{KCl}$ solution containing a mixture 
(1:1) of $1 \mathrm{mM}\left[\mathrm{Fe}(\mathrm{CN})_{6}\right]^{3-}$ and $1 \mathrm{mM}\left[\mathrm{Fe}(\mathrm{CN})_{6}\right]^{4-}$ solutions, over the frequency range of $0.1 \mathrm{~Hz}-10 \mathrm{kHz}$.

\section{Results and discussion}

\subsection{Physicochemical characterization of the clay mineral and the working electrodes}

The commercial clay mineral used in this work (Mont) is a well-characterized material, mainly composed of montmorillonite. However, prior to its use, its nature and the morphology were confirmed by XRD and SEM. Figure 2a depicts the X-ray diffraction pattern of Mont, along with its SEM picture. According to the XRD curve, the essential constituent this clay is montmorillonite as revealed by a $\mathrm{d}_{001}$ basal spacing of $1.22 \mathrm{~nm}\left(\right.$ at $\left.2 \theta=7.32^{\circ}\right)$. These results are consistent with previous data on this clay mineral [49]. Some crystalline impurities associated with montmorillonite revealed by XRD data were quartz and anorthite that were eliminated by wet sedimentation during the collection of the clay fraction with particle size $\leq 2 \mu \mathrm{m}[9,24$, 25]. The inset in Fig. 2a displaying the SEM picture of Mont shows its tendency to form aggregates of well-crystallized particles [50, 51].

SEM was also used to characterize the morphology of IPGE and Mont-IPGE. As shown in Fig. 2b, the surface of the unmodified IPGE was uniform, suggesting that the printing material (mixture of graphene ink, ethyl cellulose in cyclohexanone and terpineol) clearly identified by eye has properly adhered on the Kapton insulating material [37]. When the IPGE was modified by a thin film of montmorillonite, one could observe in Fig. $2 c$ that the clay material with an average size of $2 \mu \mathrm{m}$ is uniformly casted on the IPGE surface. As observed during experiments in the electrochemical section, this film was quite stable on the IPGE due to the inherent plastic and adhesive nature of montmorillonite clay mineral $[9,24]$.

\subsection{Electrochemical characterization of the electrodes}

To investigate the general electrochemical responses of the unmodified IPGE and Mont-IPGE, cyclic voltammetric (CV) measurements were performed in $0.1 \mathrm{M} \mathrm{KCl}$ solution containing $1 \mathrm{mM}\left[\mathrm{Fe}(\mathrm{CN})_{6}\right]^{3-}$ or $1 \mathrm{mM}\left[\mathrm{Ru}\left(\mathrm{NH}_{3}\right)_{6}\right]^{3+}$ (Fig. 3a, b). Both redox species were first analyzed at the bare IPGE and gave the expected well-defined reversible CV signals [see curves (1) in Fig. 3a, b]. The peaks current values obtained are $I_{\mathrm{pa}} 1.2 \mu \mathrm{A}$ and $I_{\mathrm{pc}} 1.25 \mu \mathrm{A}$, and $I_{\mathrm{pa}}$ $1.10 \mu \mathrm{A}$ and $I_{\mathrm{pc}} 1.45 \mu \mathrm{A}$, respectively, for $\left[\mathrm{Fe}(\mathrm{CN})_{6}\right]^{3-}$ and $\left[\mathrm{Ru}\left(\mathrm{NH}_{3}\right)_{6}\right]^{3+}$, that did not change upon multiple potential scanning. However, the CV curves at the IPGE covered by the thin film of Mont appeared different [see curves (2) in Fig. 3a, b]. The response to $\left[\mathrm{Fe}(\mathrm{CN})_{6}\right]^{3-}$ was suppressed [a decrease in the peak currents of about $83.74 \%$, curve (2) in Fig. 3a] since the clay film acts as a barrier to the negatively charged species. Such a behavior is due to electrostatic repulsions between the clay platelets and the analyte, both negatively charged [52]. By contrast, a pair of well-defined current peaks was observed for $\left[\mathrm{Ru}\left(\mathrm{NH}_{3}\right)_{6}\right]^{3+}$ probes at the Mont-IPGE [curve (2), Fig. 3b]. The CV peak current $\left(I_{\mathrm{pa}} 5.75 \mu \mathrm{A}, I_{\mathrm{pc}} 6.85 \mu \mathrm{A}\right)$ increased by ca $79.76 \%$ in comparison with that obtained at the bare IPGE, due to more favorable ion exchange. The increase in peak currents is attributed to both true physical diffusion of the positively charged $\left[\mathrm{Ru}\left(\mathrm{NH}_{3}\right)_{6}\right]^{3+}$ species that are retained by the negatively charged clay platelets via an ion exchange mechanism and due to the mass-charge transfer phenomena arising from potential scanning [53]. This
Fig. 2 a Powdered X-ray diffraction pattern of used clay mineral (M: montmorillonite, Q: quartz and $A$ : anorthite), the inset in (a) shows the SEM micrograph of the clay mineral; b and $\mathbf{c}$ correspond to SEM pictures of IPGE active surface and Mont-IPGE, respectively
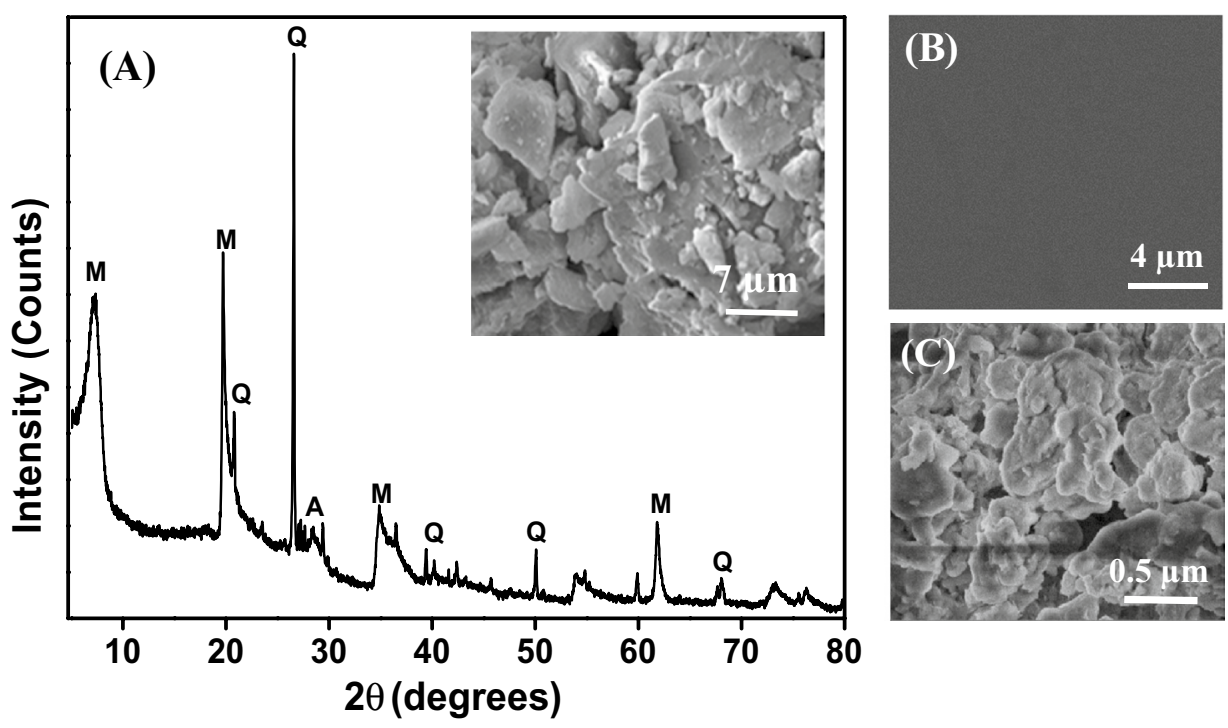

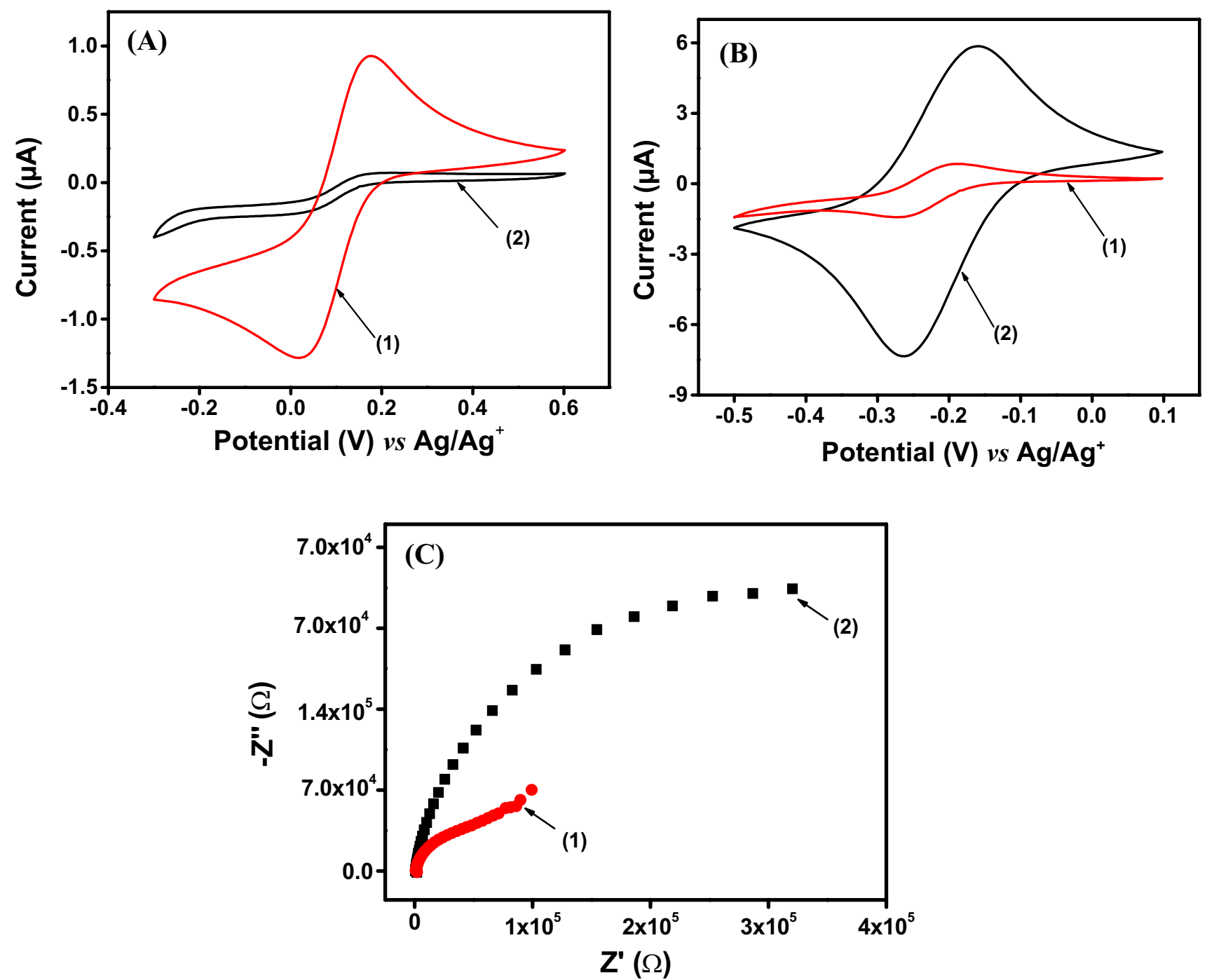

Fig. 3 Cyclic voltammograms recorded at $50 \mathrm{mV} \mathrm{s}^{-1}$ in $0.1 \mathrm{M} \mathrm{KCl}$ containing a $1 \mathrm{mM}\left[\mathrm{Fe}(\mathrm{CN})_{6}\right]^{3-}$, b $1 \mathrm{mM}\left[\mathrm{Ru}\left(\mathrm{NH}_{3}\right)_{6}\right]^{3+} \mathrm{using}(1)$ the bare IPGE and (2) Mont-IPGE; $\mathbf{c}$ Nyquist plot obtained in $0.1 \mathrm{M} \mathrm{KCl}+1 \mathrm{mM}\left[\mathrm{Fe}(\mathrm{CN})_{6}\right]^{3-/ 4-}$ on the same electrodes

result suggests that the clay film on the IPGE electrode can be exploited for the accumulation of cationic species, such as $\mathrm{Cd}^{2+}$ and $\mathrm{Pb}^{2+}$, under investigation in this work. Electrochemical impedance spectrum (EIS) was further exploited to confirm the interfacial properties of IPGE electrode before and after its modification by the thin film of Mont. As shown in Fig. 3c, the values of the resistance of charge transfer $\left(R_{C \mathrm{C}}\right)$ which is derived from the semicircle portion located at higher frequencies and characterizes the electron transfer kinetics of the redox probe at the electrode interface were $523.1 \mathrm{k} \Omega$ and $111.5 \mathrm{k} \Omega$, on Mont-IPGE and IPGE, respectively. The largest $R_{\mathrm{CT}}$ recorded on Mont-IPGE indicated a poor conductivity of this electrode because of unfavorable interactions between $\left[\mathrm{Fe}(\mathrm{CN})_{6}\right]^{3-}$ redox probe and the clay platelets, both of which bear negative charges, as observed in cyclic voltammetry data.
Meanwhile, the bare IPGE displayed the smallest $R_{\mathrm{CT}}$ due to a good electron conduction that improves the diffusion of $\left[\mathrm{Fe}(\mathrm{CN})_{6}\right]^{3-}$ toward the electrode surface as observed in similar and previous studies $[46,47]$. As partial conclusion, the EIS results indicated that the IPGE covered by a thin film of Mont could serve to accumulate cationic species.

\subsection{Electroanalytical detection of heavy metal ions}

The efficiency of IPGE and Mont-IPGE toward the detection of $\mathrm{Cd}^{2+}$ and $\mathrm{Pb}^{2+}$ ions and the effect of the presence of $\mathrm{Bi}^{3+}$ ions in the supporting electrolyte were investigated. Yet, the addition of $\mathrm{Bi}^{3+}$ ions in the accumulation medium during the electrochemical detection of heavy metals by stripping analysis has been shown to favor the formation of alloys with these metals, thereby facilitating their 


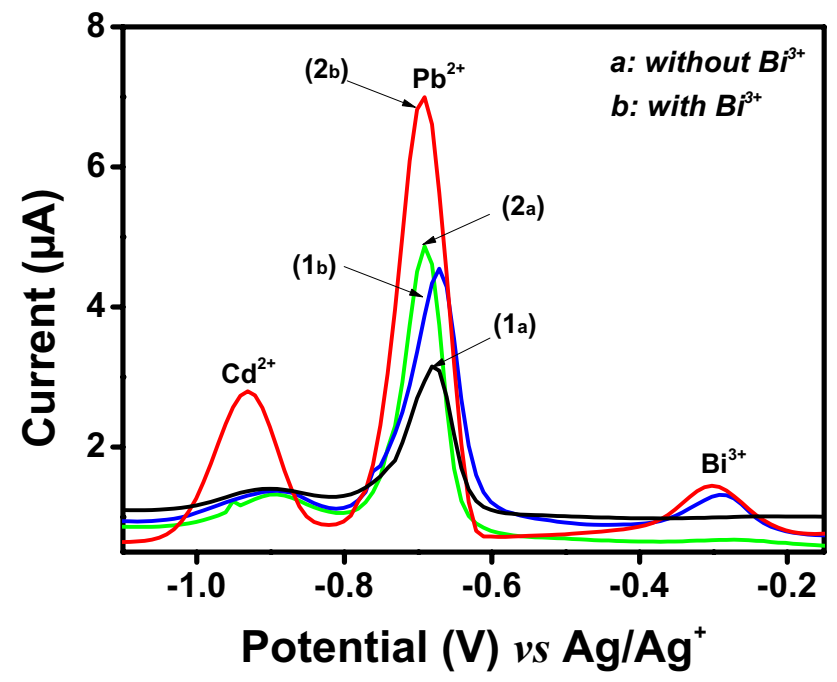

Fig. 4 SWV curves obtained without $\mathrm{Bi}^{3+}$ ions in the supporting electrolyte, on bare IPGE (1a, black) and Mont-IPGE (2a, red), and upon addition of $\mathrm{Bi}^{3+}$ ions in the supporting electrolyte (final concentration: $2 \mu \mathrm{M}$ ) on IPGE (1b, dark yellow) and on Mont-IPGE ( $2 \mathrm{~b}$, blue). Detection was performed in $0.1 \mathrm{M} \mathrm{ABS} \mathrm{pH} 4.5$ containing $2 \mu \mathrm{M}$ of $\mathrm{Cd}^{2+}$ and $\mathrm{Pb}^{2+}$ ions. Accumulation time: $180 \mathrm{~s}$

accumulation by co-deposition [54, 55]. Figure 4 shows the square wave anodic stripping voltammograms of $2 \mu \mathrm{MCd}^{2+}$ and $\mathrm{Pb}^{2+}$ ions recorded at the bare IPGE and at Mont-IPGE under the same conditions. As one can notice, the investigated analytes were detected on both electrodes without $\mathrm{Bi}^{3+}$ in the supporting electrolyte (curves $1 \mathrm{a}$ and $2 \mathrm{a}$ in Fig. 4). It can be also observed that both electrodes were more sensitive to $\mathrm{Pb}^{2+}$ ions: The recorded peak currents were $4.00 \mu \mathrm{A}$ (Mont-IPGE) and $2.03 \mu \mathrm{A}$ (IPGE) for $\mathrm{Pb}^{2+}$ ions on one hand, $0.35 \mu \mathrm{A}$ and $0.11 \mu \mathrm{A}$, respectively, at the same electrodes for $\mathrm{Cd}^{2+}$ ions on the other hand. Upon the addition of $\mathrm{Bi}^{3+}$ to a final concentration of $2 \mu \mathrm{M}$ in the supporting, a significant increase in the signals of investigated heavy metals ions was observed: the peak currents registered on the bare IPGE were $3.39 \mu \mathrm{A}$ and $0.19 \mu \mathrm{A}$ for $\mathrm{Pb}^{2+}$ and $\mathrm{Cd}^{2+}$ ions, respectively (curve $1 \mathrm{~b}$, Fig. 4), while these currents increase to $6.14 \mu \mathrm{A}$ and $1.96 \mu \mathrm{A}$ on Mont-IPGE (curve 2b, Fig. 4). This increase in the electrode signals from curve $1 \mathrm{a}$ to curve $2 \mathrm{a}$ is due to the presence of Mont on the IPGE, since this clay mineral possesses surface reactive hydroxyl $(-\mathrm{OH})$ groups able to adsorb $\mathrm{Pb}^{2+}$ and $\mathrm{Cd}^{2+}$ ions [56]. Yet, the reactivity of claymodified electrodes is dependent from the sorption ability, the exchange capacity and the surface area of the clay material bound at the solid electrode [57]. The addition of $\mathrm{Bi}^{3+}$ ions in detection medium further increases both IPGE and Mont-IPGE responses (Fig. 3, curves $1 \mathrm{~b}$ and $2 \mathrm{~b}$ ) for the stripping detection of $\mathrm{Pb}^{2+}$ and $\mathrm{Cd}^{2+}$ ions due to the ability of bismuth to form "fused" alloys with cadmium and lead, making them easier to be accumulated before their electrochemical reduction [58,59], as observed in previous studies on the role of bismuth in preconcentration electroanalysis dedicated to trace analysis of heavy metals [60-62]. Moreover, the oxidation peak potentials of both $\mathrm{Pb}^{2+}$ and $\mathrm{Cd}^{2+}$ ions slightly shifted to more negative potentials on Mont-IPGE, due to the electrocatalytic effect of the clay mineral. These observations clearly demonstrate the feasibility of using the ink-jet-printed electrode modified by a thin film of clay mineral as low-cost sensing electrode for the detection of $\mathrm{Pb}^{2+}$ and $\mathrm{Cd}^{2+}$ ions. The optimization of key parameters effecting the electroanalysis of these species was undertaken in the coming section.

\subsection{Optimization of experimental parameters for heavy metals detection on Mont-IPGE}

Some parameters likely to affect the sensitivity of Mont-IPGE toward the stripping analysis of $\mathrm{Pb}^{2+}$ and $\mathrm{Cd}^{2+}$ including the amount of Mont on IPGE, the concentration of $\mathrm{Bi}^{3+}$ ions in the detection medium, the $\mathrm{pH}$ of detection medium, the deposition potential and time were optimized.

\subsubsection{Influence of the amount of Mont on the electrode}

It was shown from preliminary studies that the presence of the clay mineral on the IPGE has induced an increase in the electrode response. Thus, the purified water volume was kept at $1 \mathrm{~mL}$ while the amount of Mont was varied from 0.5 to $5 \mu \mathrm{g}$. Figure 5 presents the effect of the amount of Mont in the dispersion used to modify the ink-jet-printed electrode. As observed in IPGE and Mont-IPGE, the current

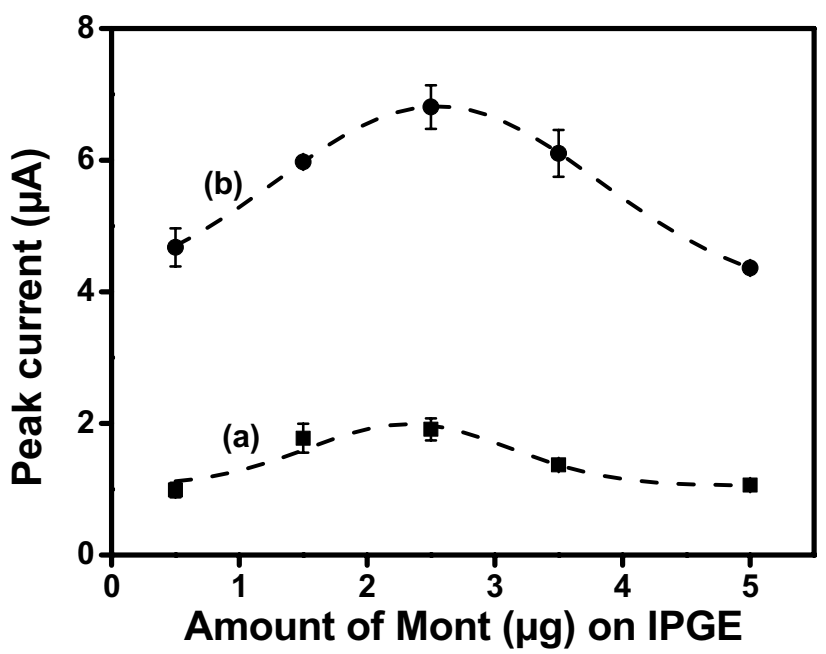

Fig. 5 Effect of the amount of Mo (in $\mu \mathrm{g}$ ) on the SWV peak current of $2 \mu \mathrm{M} \mathrm{Cd}^{2+}(\mathrm{a})$ and $\mathrm{Pb}^{2+}$ (b) on Mont-IPGE recorded in $0.1 \mathrm{M}$ acetate buffer ( $\mathrm{pH} 4.5)$. Electrolysis potential: $-1.1 \mathrm{~V}$, electrolysis deposition: $180 \mathrm{~s}$. The experiments were performed in triplicate 
signal increased with the increase in clay mass from 0.5 to $2.5 \mu \mathrm{g}$ where the binding sites on the clay-modified electrode become saturated. Afterward, the electrode response decreased, the clay film becoming too thick and acting as a physical barrier for the electron transfer. Hence, the concentration of $2.5 \mu \mathrm{g} \mathrm{mL}^{-1}$ was selected for the subsequent study. This result demonstrates that the montmorillonite clay can be exploited to remarkably improve the sensitivity of the IPGE electrode, owing to its ion exchange ability and high adsorption capacity.

\subsubsection{Influence of $\mathrm{Bi}^{3+}$ ions concentration}

The preliminary tests also revealed that the presence of $\mathrm{Bi}^{3+}$ ions in the detection solution can enhance the signals of the target analytes. Thus, the concentration of $\mathrm{Bi}^{3+}$ ions in the supporting electrolyte appears to be another critical parameter for SWASV because these ions contribute to increase the amount of bounded $\mathrm{Pb}^{2+}$ or $\mathrm{Cd}^{2+}$ ions, thereby affecting the sensitivity of Mont-IPGE sensor. Figure 6 shows the effect of the concentration of $\mathrm{Bi}^{3+}$ ions $(0,0.1,2,10 \mu \mathrm{M})$ on the peak currents of $\mathrm{Cd}^{2+}$ and $\mathrm{Pb}^{2+}$ ions $(2 \mu \mathrm{M})$. The stripping peak currents of $\mathrm{Cd}^{2+}$ and $\mathrm{Pb}^{2+}$ increased with $\mathrm{Bi}^{3+}$ concentration from 0 to $2 \mu \mathrm{M}$ and then decreased slightly in the range from 2 to $10 \mu \mathrm{M}$. Thicker bismuth films may probably impede mass transfer between the binding sites of target analyte and the conductive substrate of the working electrode, resulting in a decrease in current response after the maximum value is reached. $\mathrm{A} \mathrm{Bi}^{3+}$ concentration of $2 \mu \mathrm{M}$ was used as the optimal value in subsequent experiments.

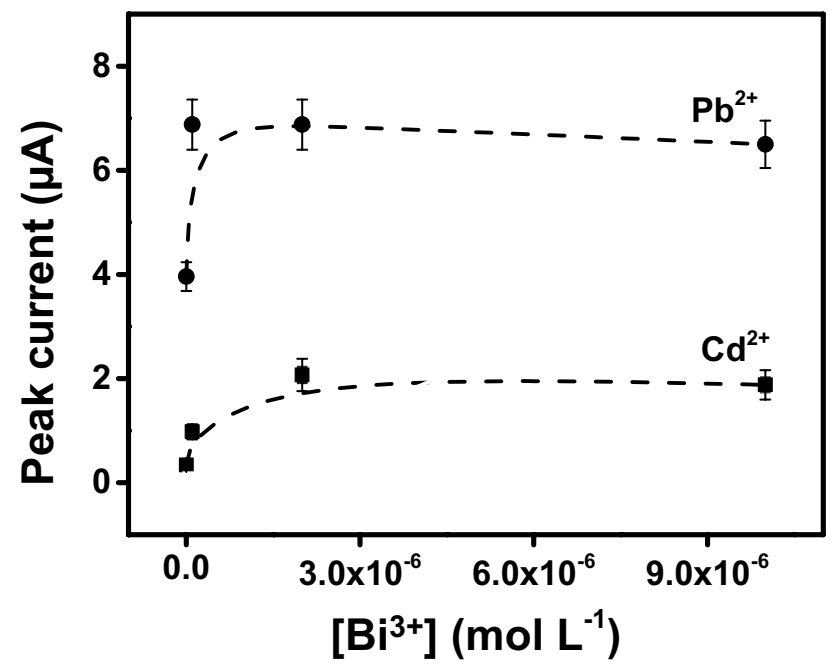

Fig. 6 Effect of $\mathrm{Bi}^{3+}$ ions concentration on the SWV peak current of $2 \mu \mathrm{M} \mathrm{Cd}^{2+}+\mathrm{Pb}^{2+}$ on Mont-IPGE in $0.1 \mathrm{M} \mathrm{ABS} \mathrm{pH} 4.5$ (electrolysis potential: $-1.1 \mathrm{~V}$, electrolysis time: $180 \mathrm{~s}$ )

\subsubsection{Influence of $\mathrm{pH}$ on the electrode response}

The acidity of the buffer solution used as accumulating and detecting solution, expected to influence the sensitivity of Mont-IPGE sensor, was optimized. The study was limited to acidic media where the studied ions are in cationic form and to avoid the complexation of $\mathrm{Cd}^{2+}$ and $\mathrm{Pb}^{2+}$ that may occur in basic solutions. It can be observed from Fig. 7 that the stripping peak currents of $\mathrm{Cd}^{2+}$ and $\mathrm{Pb}^{2+}$ increased with the $\mathrm{pH}$ value from 3.5 to 4.5 and then decreased in the range from 4.5 to 5.5 . Almost weak from 3.5 , the $\mathrm{pH}$ increased progressively to reach a maximum at 4.5 , and it then decreased till 5.5. Therefore, the $\mathrm{pH} 4.5$ was selected as the optimal $\mathrm{pH}$ value in the subsequent experiment.

\subsubsection{Effect of electrolysis potential and accumulation time}

The electrolysis step is mainly governed by two parameters: the potential at which each metal ion is reduced, and the duration for that potential to be applied. The electrolysis potential was investigated from -1.4 to $-0.9 \mathrm{~V}$ in $0.1 \mathrm{M}$ ABS pH 4.5 containing $2 \mu \mathrm{M} \mathrm{Cd}^{2+}$ and $\mathrm{Pb}^{2+}$ in the presence of $2 \mu \mathrm{M} \mathrm{Bi}^{3+}$ ions. The results are shown in Fig. 8 a. The reduction in both analytes was affected by the potential, and the convenient domain for their significant detection was observed to lie between $-1.4 \mathrm{~V}$ and $-1.2 \mathrm{~V}$. More negative potentials did not induce a significant change in the stripping peak heights. However, a decrease in the peak currents of $\mathrm{Cd}^{2+}$ and $\mathrm{Pb}^{2+}$ occurred at electrolysis potentials between -1.2 and $-0.9 \mathrm{~V}$. Considering the stripping currents of $\mathrm{Cd}^{2+}$ and $\mathrm{Pb}^{2+}$ ions, $-1.3 \mathrm{~V}$ was chosen

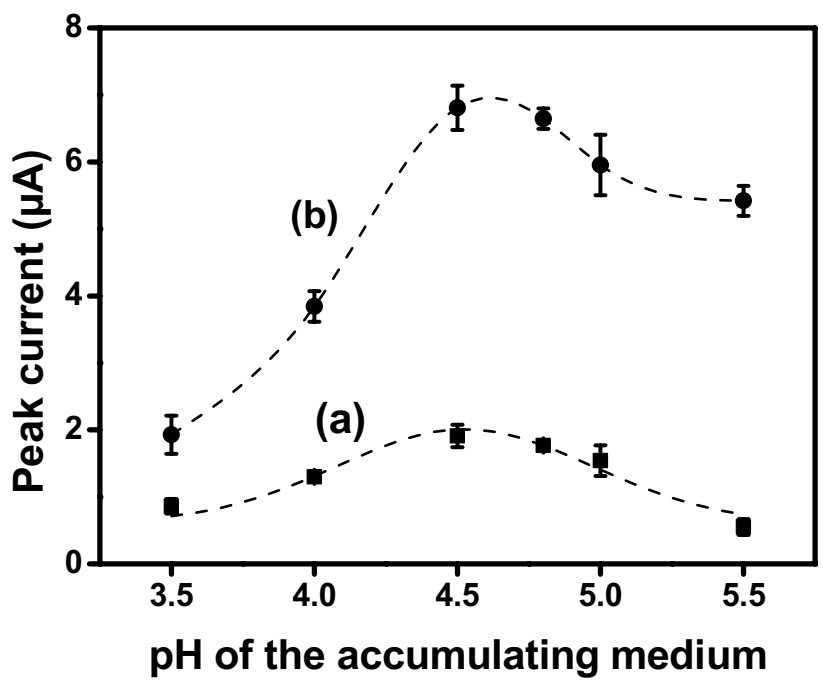

Fig. 7 Effect at Mont-IPGE of the pH of $0.1 \mathrm{M}$ acetate buffer solution used as preconcentration/detection medium on the peak current of $2 \mu \mathrm{M} \mathrm{Cd}^{2+}$ and $\mathrm{Pb}^{2+}$ (electrolysis potential: $-1.1 \mathrm{~V}$, electrolysis time: $180 \mathrm{~s}$ ). Experiments were performed in triplicate 

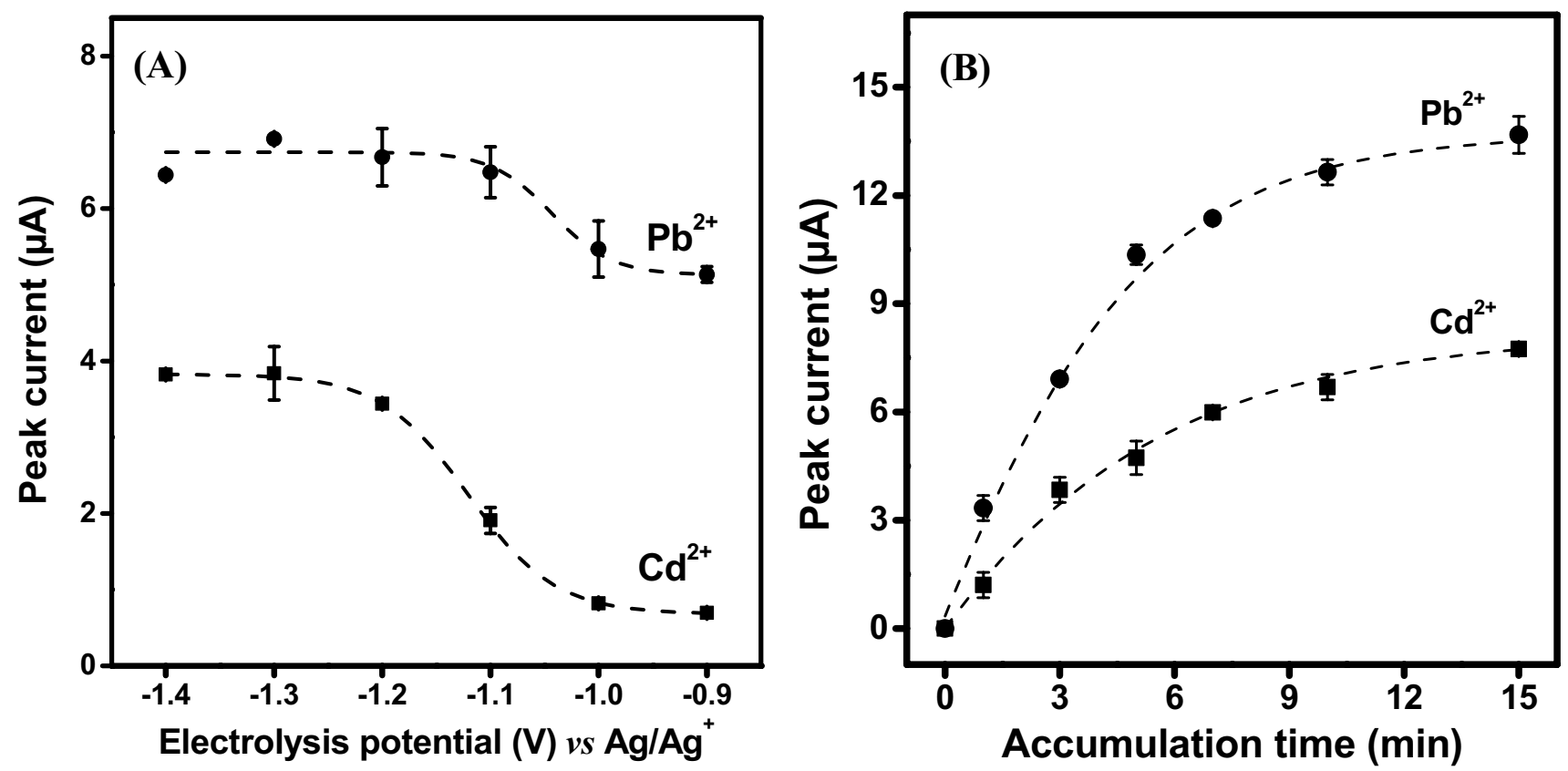

Fig. 8 a Effect of electrolysis potential and $\mathbf{b}$ accumulation time on the SWV peak currents of $2 \mu \mathrm{M} \mathrm{Cd^{2+ }}$ and Pb ${ }^{2+}$ on Mont-IPGE in $0.1 \mathrm{M}$ ABS pH 4.5. Experiments were performed in triplicate

as the optimal electrolysis potential for further measurements. The effect of the accumulation time was also evaluated within the range from 0 to $15 \mathrm{~min}$, and the results are presented in Fig. $8 \mathrm{~b}$. The response gradually increased with accumulation time up to $7 \mathrm{~min}$ and a plateau was observed between 7 and 15 min, which indicates the saturation of the binding sites on the Mont-IPGE. For further analysis, the deposition time was chosen to be $5 \mathrm{~min}$.

\subsection{Calibration curves, reproducibility, interference study and analytical application}

\subsubsection{Calibration curve and reproducibility}

The analytic performance of Mont-IPGE sensor was investigated by applying the optimized experimental conditions achieved in previous sections, toward the detection of $\mathrm{Cd}^{2+}$ and $\mathrm{Pb}^{2+}$ ions. Figure 9 presents the voltammograms recorded in $0.1 \mathrm{M} \mathrm{ABS}$ when the concentration of $\mathrm{Cd}^{2+}$ and $\mathrm{Pb}^{2+}$ was varied from 0.01 to $0.21 \mu \mathrm{M}$. It was observed for each metal ion that the peak current increases with the concentration. The corresponding calibration curves are illustrated by the inset in Fig. 9: For both analytes, the current response increases linearly with the metal ion concentration.

The correlation equations were defined as $\mathrm{Ip}(\mathrm{A})=9.218\left[\mathrm{Cd}^{2+}\right](\mu \mathrm{M})+2.625 \times 10^{-7}(R=0.998)$ for $\mathrm{Cd}^{2+}$ ions and $\mathrm{Ip}(\mathrm{A})=19.608 \times\left[\mathrm{Pb}^{2+}\right](\mu \mathrm{M})-9.218 \times 10^{-8}$ $(R=0.999)$ for $\mathrm{Pb}^{2+}$ ions, respectively. The sensitivity

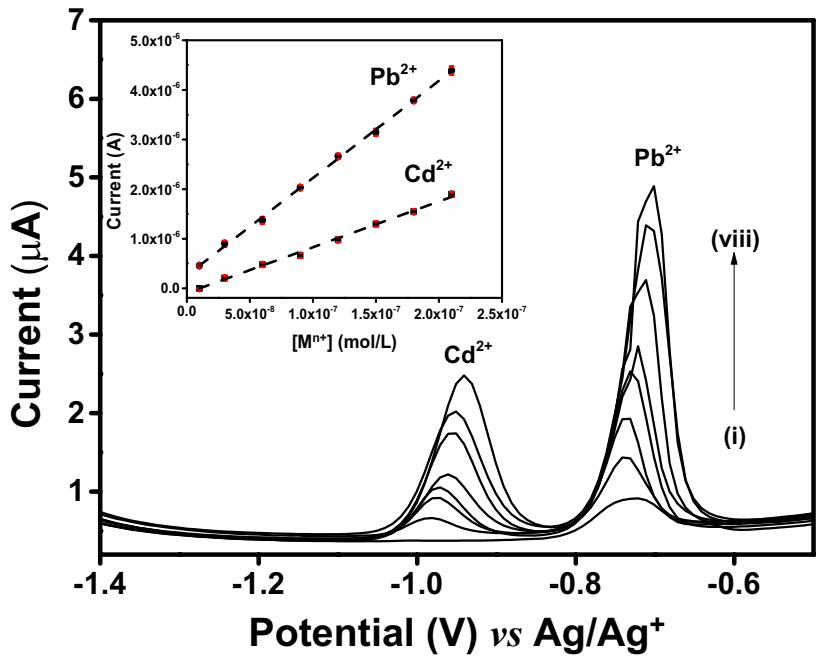

Fig. 9 SWV curves recorded under optimized conditions for $\mathrm{Cd}^{2+}$ and $\mathrm{Pb}^{2+}$ ions (from 0.01 to $0.21 \mu \mathrm{M}$ ) in $0.1 \mathrm{M} \mathrm{ABS}$ at $\mathrm{pH} 4.5$, using Mont-IPGE. Inset shows the corresponding calibration curves (data recorded in triplicate)

of the electrode for $\mathrm{Cd}^{2+}$ ions is $921.8 \mathrm{~A} \mathrm{~cm}^{-2} \mathrm{M}^{-1}$ and $1960.8 \mathrm{~A} \mathrm{~cm}^{-2} \mathrm{M}^{-1}$ for $\mathrm{Pb}^{2+}$ ions. Based on a minimum signal-to-noise ratio of 3 , the detection limits were estimated to be $0.42 \mathrm{nM}$ for $\mathrm{Cd}^{2+}$ and $1.14 \mathrm{nM}$ for $\mathrm{Pb}^{2+}$ ions. These analytical performances are comparable or better than some data reported in the previous literature for both metals $[9,38,57,63-69]$, as shown in Table 1.

\section{SN Applied Sciences}


Table 1 Comparison of the performance of some $\mathrm{Cd}^{2+}$ and $\mathrm{Pb}^{2+}$ ion sensors

\begin{tabular}{|c|c|c|c|c|c|}
\hline Description of the working electrode & Analyte & $\begin{array}{l}\text { Limit of detec- } \\
\text { tion }(n M)\end{array}$ & $\begin{array}{l}\text { Analytical tech- } \\
\text { nique }\end{array}$ & Sample & References \\
\hline \multirow[t]{2}{*}{$\mathrm{GCE} / \mathrm{Sa}\left(\mathrm{CTA}_{0.25}, \mathrm{~T}\right)^{(1)}$} & $\mathrm{Cd}^{2+}$ & 1.2 & SWASV & - & [9] \\
\hline & $\mathrm{Pb}^{2+}$ & 0.42 & & & \\
\hline \multirow[t]{2}{*}{ IL-CNT-GF electrode ${ }^{(2)}$} & $\mathrm{Cd}^{2+}$ & 0.1 & DPASV & East lake water, tap water & [38] \\
\hline & $\mathrm{Pb}^{2+}$ & 0.2 & & & \\
\hline \multirow[t]{2}{*}{ Nano-SWy-2-AQ/GCE ${ }^{(3)}$} & $\mathrm{Cd}^{2+}$ & 3 & DPASV & Milk powder, lake water & {$[57]$} \\
\hline & $\mathrm{Pb}^{2+}$ & 1 & & & \\
\hline \multirow[t]{2}{*}{$\mathrm{SPE}^{(4)}$ modified with bismuth citrate } & $\mathrm{Cd}^{2+}$ & 9.79 & SWASV & Tap water, mineral water & {$[63]$} \\
\hline & $\mathrm{Pb}^{2+}$ & 4.34 & & & \\
\hline \multirow[t]{2}{*}{$\mathrm{SPCE}-\mathrm{Bi}_{2} \mathrm{O}_{3}-\mathrm{PSS}-\mathrm{CnP} \mathrm{P}^{(5)}$ membrane } & $\mathrm{Cd}^{2+}$ & 0.11 & DPASV & Mineral water, natural water & {$[64]$} \\
\hline & $\mathrm{Pb}^{2+}$ & 0.14 & & & \\
\hline \multirow[t]{2}{*}{ Screen-printed bismuth oxide } & $\mathrm{Cd}^{2+}$ & 13.34 & SWASV & Real water samples & {$[65]$} \\
\hline & $\mathrm{Pb}^{2+}$ & 11.1 & & & \\
\hline \multirow[t]{2}{*}{ MWCNTs-NA/Bi/GCE ${ }^{(6)}$} & $\mathrm{Cd}^{2+}$ & 0.357 & DPASV & Tap water & {$[66]$} \\
\hline & $\mathrm{Pb}^{2+}$ & 0.12 & & & \\
\hline \multirow[t]{2}{*}{ Bismuth film electrode } & $\mathrm{Cd}^{2+}$ & 1.77 & SWASV & Tap water, human hair & {$[67]$} \\
\hline & $\mathrm{Pb}^{2+}$ & 0.966 & & & \\
\hline \multirow[t]{2}{*}{$\mathrm{Bi} /$ poly $(p A B S A) / G C E^{(7)}$} & $\mathrm{Cd}^{2+}$ & 5.6 & DPASV & River water samples & {$[68]$} \\
\hline & $\mathrm{Pb}^{2+}$ & 3.86 & & & \\
\hline \multirow[t]{2}{*}{ Bi/Au-GN-Cys/GCE ${ }^{(8)}$} & $\mathrm{Cd}^{2+}$ & 0.89 & SWASV & Real water sample & [69] \\
\hline & $\mathrm{Pb}^{2+}$ & 0.24 & & & \\
\hline \multirow[t]{2}{*}{ Mo/2L-IPGE ${ }^{(9)}$} & $\mathrm{Cd}^{2+}$ & 0.42 & SWASV & Mineral water & This work \\
\hline & $\mathrm{Pb}^{2+}$ & & & & \\
\hline
\end{tabular}

(1) Glassy carbon electrode covered by a thin film of smectite clay obtained by co-intercalation of thiourea and CTA ${ }^{+}$ions, (2) ionic liquid-carbon nanotube-graphene film, (3) clay nanoparticles and anthraquinone complexly modified glassy carbon electrode, (4) screenprinted electrode, (5) disposable screen-printed electrode modified with bismuth-polystyrene sulfonate composite, (6) multiwall carbon nanotubes-nafion/bismuth composite electrodes, (7) bismuth/poly(p-aminobenzene sulfonic acid) film on glassy carbon electrode, (8) gold nanoparticle-graphene-cysteine composite modified bismuth film electrode, (9) 2 layers ink-jet-printed graphene electrode modified by a film of montmorillonite

The reproducibility of the Mont-IPGE sensor was evaluated prior to its exploitation in real sample analysis. Thus, three Mont-IPGE electrodes were prepared in the same way and used for the detection in $0.1 \mathrm{M}$ ABS (pH 4.5) of a solution containing $2 \mu \mathrm{M}$ of $\mathrm{Cd}^{2+}$ and $\mathrm{Pb}^{2+}$ ions. Each electrode was used for five repetitive stripping voltammograms. The results showed that Mont-IPGE presents excellent reproducibility for cadmium and lead detection since a relative standard deviation of $3.06 \%$ was observed between the prepared electrodes while a standard deviation of $2.11 \%$ was registered for the 5 measurements. These results showed a good reproducibility of the proposed IPGEclay-modified electrode.

\subsubsection{Interference study and analytical application}

The effect of eventual interfering species on the signals of $\mathrm{Cd}^{2+}$ and $\mathrm{Pb}^{2+}$ ions $(0.5 \mu \mathrm{M}$ of each ion in the mixture) was carefully examined. Thus, $\mathrm{Zn}^{2+}, \mathrm{Fe}^{2+}, \mathrm{Cr}^{3+}$, $\mathrm{Cu}^{2+}, \mathrm{Ni}^{2+}$ and $\mathrm{Zn}^{2+}$ ions were added at various concentrations (typically 1,50 and $100 \mu \mathrm{M}$ ) in the accumulation medium that correspond, respectively, to 2-, 100- and 200-fold excess over $\mathrm{Cd}^{2+}$ and $\mathrm{Pb}^{2+}$ target analytes concentration. Most of these metal ions did not interfere significantly in the detection of $\mathrm{Cd}^{2+}$ and $\mathrm{Pb}^{2+}: \mathrm{Zn}^{2+}$, $\mathrm{Fe}^{2+}, \mathrm{Cr}^{3+}, \mathrm{Ni}^{2+}$ and $\mathrm{Zn}^{2+}$ event added in the accumulation medium at a concentration 200-fold higher than that of the analytes did not significantly influence the signal of $\mathrm{Cd}^{2+}$ and $\mathrm{Pb}^{2+}$ as the observed variations in peak currents were below the tolerance limit defined as the concentration ratio of interfering $/\left(\mathrm{Pb}^{2+}+\mathrm{Cd}^{2+}\right)$ causing less than $\pm 5.0 \%$ relative error. However, $\mathrm{Cu}^{2+}$ was pointed to be the most interfering ion since its addition at $0.5 \mu \mathrm{M}$ induced a diminution of the analytes' signals for about $50 \%$ (Fig. 10), as a result of a competition of $\mathrm{Cu}^{2+}$ with $\mathrm{Bi}^{3+}, \mathrm{Pb}^{2+}$ and $\mathrm{Cd}^{2+}$ for the electrodeposition on the surface of the clay-modified electrode $[54,55]$. 


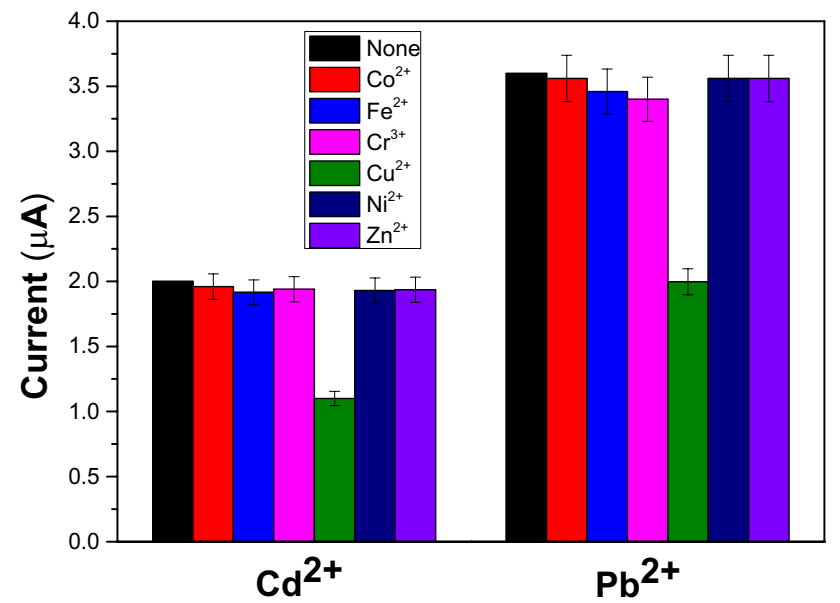

Fig. 10 Effect of some typical metal ions on the peak currents of $0.5 \mu \mathrm{M} \mathrm{Cd} d^{2+}$ and $0.5 \mu \mathrm{M} \mathrm{Pb}^{2+}$ ions in $0.1 \mathrm{M} \mathrm{ABS}$ at $\mathrm{pH} 4.5$, at the Mont-IPGE sensor. The concentration of interfering species is 200fold excess over $\mathrm{Cd}^{2+}$ and $\mathrm{Pb}^{2+}$ target analytes concentration

This has a significant influence on the stripping signals of the investigated analytes, which somewhat limits the application of the proposed sensor for the analysis of samples expected to contain $\mathrm{Cu}^{2+}$ ions.

Finally, the Mont-IPGE sensor was applied to the analysis of $\mathrm{Pb}^{2+}$ and $\mathrm{Cd}^{2+}$ in a mineral water, under the optimized conditions. The mineral water was stored at $4{ }^{\circ} \mathrm{C}$ in a refrigerator immediately after collection from a local market, and no pretreatment was made before the analysis. The label of this water shows that it contains $\mathrm{Ca}^{2+}(30 \mathrm{mg} / \mathrm{L}), \mathrm{Mg}^{2+}(5.9 \mathrm{mg} / \mathrm{L})$ and $\mathrm{K}^{+}(3.8 \mathrm{mg} / \mathrm{L})$ cations, which are equivalent to $750 \mu \mathrm{M}, 242.7 \mu \mathrm{M}$ and $97.4 \mu \mathrm{M}$ for $\mathrm{Ca}^{2+}, \mathrm{Mg}^{2+}$ and $\mathrm{K}^{+}$, respectively, in terms of concentrations. The real water sample was conditioned with a $0.1 \mathrm{M}$ acetate buffer solution (at $\mathrm{pH} 4.5$ ) containing $2 \mu \mathrm{M} \mathrm{Bi}^{3+}$. The solution was then transferred into the voltammetric cell to be analyzed without any further treatment. As shown in Table 2, a relatively low average recovery rate was obtained for mineral water sample spiked with $\mathrm{Cd}^{2+}(67.11 \%)$ and $\mathrm{Pb}^{2+}(72.64 \%)$ ions. This suggests that the Mont-IPGE sensor is less selective in the analysis of mineral water which contains high amounts of $\mathrm{Ca}^{2+}$ and $\mathrm{Mg}^{2+}$ ions. Yet, these ions can easily be adsorbed within the montmorillonite interlayer space. This issue could be probably solved by modifying the IPGE by montmorillonite previously grafted by specific chelating groups displaying a great affinity toward the target analytes.

\section{Conclusion}

A low-cost and highly sensitive method for $\mathrm{Cd}^{2+}$ and $\mathrm{Pb}^{2+}$ ions determination was developed, based on montmorillonite-type clay mineral, which formed a quite stable thin film on ink-jet-printed graphene electrodes (IPGE). The ion exchange ability and high adsorption capacity of the clay mineral at the IPGE were exploited to elaborate a sensor applied for the detection of $\mathrm{Cd}^{2+}$ and $\mathrm{Pb}^{2+}$ ions using SWASV. $\mathrm{Cd}^{2+}$ and $\mathrm{Pb}^{2+}$ ions were shown to be well concentrated on the clay-modified electrode surface with the addition of $\mathrm{Bi}^{3+}$ ions in the detection medium, under the application of a negative potential. The combination of the ion exchange ability of clay mineral with the electronic conduction of graphene material allows to achieve best results in terms of sensitivity. This work demonstrates the resort to clay minerals as potential modifier for disposable ink-jet-printed electrodes.
Table 2 Data obtained in the determination $0.21 \mu \mathrm{M} \mathrm{Cd}^{2+}$ and $\mathrm{Pb}^{2+}$ ions in a mineral water sample using Mont-IPGE sensor

\begin{tabular}{|c|c|c|c|c|c|c|c|c|}
\hline & \multicolumn{2}{|c|}{ Added $(\mu \mathrm{M})$} & \multicolumn{2}{|c|}{ Found $^{\mathrm{b}}(\mu \mathrm{M})$} & \multicolumn{2}{|c|}{ RSD (\%) } & \multicolumn{2}{|c|}{ Recovery (\%) } \\
\hline & $\overline{\mathrm{Cd}^{2+}}$ & $\mathrm{Pb}^{2+}$ & $\mathrm{Cd}^{2+}$ & $\mathrm{Pb}^{2+}$ & $\mathrm{Cd}^{2+}$ & $\mathrm{Pb}^{2+}$ & $\mathrm{Cd}^{2+}$ & $\mathrm{Pb}^{2+}$ \\
\hline \multirow[t]{2}{*}{${ }^{\mathrm{a}}$ Mineral water } & 0 & 0 & $N D^{c}$ & $N^{c}$ & - & - & - & - \\
\hline & 0.21 & 0.21 & 0.14 & 0.15 & 2.66 & 3.02 & 67.11 & 72.64 \\
\hline
\end{tabular}

ND not determined

${ }^{a}$ The mineral water sample was collected from a local market in Dschang, Cameroun

${ }^{\mathrm{b}}$ Mean of three measurements

${ }^{\mathrm{c}}$ Mean of three measurements 
Acknowledgements LSG grateful acknowledges the support of the EPFL (Switzerland) for all facilities, as well as the Ministry of Higher Education (Cameroon) for a travel grant. The support of the Alexander von Humboldt Foundation (Germany) is also acknowledged.

\section{Compliance with ethical standards}

Conflict of interest The authors declare that they have no conflict of interest.

\section{References}

1. Bansoda BK, Kumar T, Thakur R, Rana S, Singh I (2017) A review on various electrochemical techniques for heavy metal ions detection with different sensing platforms. Biosens Bioelectron 94:443-455. https://doi.org/10.1016/j.bios.2017.03.031

2. Xiong S, Yang B, Cai D, Qiu G, Wu Z (2015) Individual and simultaneous stripping voltammetric and mutual interference analysis of $\mathrm{Cd}^{2+}, \mathrm{Pb}^{2+}$ and $\mathrm{Hg}^{2+}$ with reduced graphene oxide- $\mathrm{Fe}_{3} \mathrm{O}_{4}$ nanocomposites. Electrochim Acta 185:52-61. https://doi. org/10.1016/j.electacta.2015.10.114

3. Guo Z, Seol ML, Gao C, Kim MS, Ahn JH, Choi YK, Huang X (2016) Functionalized porous Si nanowires for selective and simultaneous electrochemical detection of $\mathrm{Cd}(\mathrm{II})$ and $\mathrm{Pb}$ (II) ions. Electrochim Acta 211:998-1005. https://doi.org/10.1016/j.elect acta.2016.06.141

4. World Health Organization (2011) Guidelines for drinking-water quality. Background document, 4th edn. WHO, Geneva

5. Bagheri H, Afkhami A, Saber-Tehrani M, Khoshsafar H (2012) Preparation and characterization of magnetic nanocomposite of Schiff base/silica/magnetite as a preconcentration phase for the trace determination of heavy metal ions in water, food and biological samples using atomic absorption spectrometry. Talanta 97:87-95. https://doi.org/10.1016/j.talanta.2012.03.066

6. Guzman-Mar JL, Hinojosa-Reyes L, Serra AM, Hernandez-Ramirez A, Cerda V (2011) Applicability of multi syringe chromatography coupled to cold-vapor atomic fluorescence spectrometry for mercury speciation analysis. Anal Chim Acta 708:11-18. https ://doi.org/10.1016/j.aca.2011.09.037

7. Zeng W, Chen Y, Cui H, Wu F, Zhu Y, Fritz JS (2006) Single-column method of ion chromatography for the determination of common cations and some transition metals. J Chromatogr A 1118:68-72. https://doi.org/10.1016/j.chroma.2006.01.065

8. Arpadjan S, Celix G, Taskesen S, Gucer S (2008) Arsenic, cadmium and lead in medicinal herbs and their fractionation. Food Chem Toxicol 46:2871-2875. https://doi.org/10.1016/j.fct.2008.05.027

9. Ngassa GBP, Tonle IK, Walcarius A, Ngameni E (2016) An inorganic-organic hybrid material from the co-intercalation of a cationic surfactant and thiourea within montmorillonite layers: application to the sensitive stripping voltammetric detection of $\mathrm{Pb}^{2+}$ and $\mathrm{Cd}^{2+}$ ions. C R Chimie 19:789-797. https://doi. org/10.1016/j.crci.2015.08.008

10. Wang J, Deo RP, Thongngamdee S, Ogorevc B (2001) Effect of surface-active compounds on the stripping voltammetric response of bismuth film electrodes. Electroanalysis 13:11531156. https://doi.org/10.1002/1521-4109(200110)

11. Chen B, Wang L, Huang X, Wu P (2011) Glassy carbon electrode modified with organic-inorganic pillared montmorillonites for voltammetric detection of mercury. Microchim Acta 172:335341. https://doi.org/10.1007/s00604-010-0457-3

12. Gold V, Loening KL, Mc Naught AD, Sehmi P (1987) Compendium of chemical terminology, IUPAC recommendation. Blackwell Scientific Publication, Oxford
13. Barroso MF, De-los-Santos-Alvarez N, Delerue-Matos C, Oliveira MBPP (2011) Towards a reliable technology for antioxidant capacity and oxidative damage evaluation: electrochemical (bio)sensors. Biosens Bioelectron 30:1-12. https://doi. org/10.1016/j.bios.2011.08.036

14. Sochor J, Dobes J, Krystofova O, Ruttkay-Nedecky B, Babula P, Pohanka M, Jurikova T, Zitka O, Adam V, Klejdus B, Kizek R (2013) Electrochemistry as a tool for studying antioxidant properties. Int J Electrochem Sci 8:8464-8489

15. Chevion S, Roberts MA, Chevion M (2000) The use of cyclic voltammetry for the evaluation of antioxidant capacity. Free Radic Biol Med 28:860-870. https://doi.org/10.1016/S0891 $-5849(00) 00178-7$

16. Kilmartin PA, Zou H, Waterhouse AL (2001) A cyclic voltammetry method suitable for characterizing antioxidant properties of wine and wine Phenolics. J Agric Food Chem 49:1957-1965. https://doi.org/10.1021/jf001044u

17. McBride HD, Evans DH (1973) Rapid voltammetric method for the estimation of tocopherols and antioxidants in oils and fats. Anal Chem 45:446-449. https://doi.org/10.1021/ac60325a003

18. Blasco AJ, Gonzalez MC, Escarpa A (2004) Electrochemical approach for discriminating and measuring predominant flavonoids and phenolic acids using differential pulse voltammetry: towards an electrochemical index of natural antioxidants. Anal Chim Acta 511:71-81. https://doi.org/10.1016/j. aca.2004.01.038

19. Emami M, Shamsipur M, Saber R (2014) Design of poly-Imethionine-gold nanocomposite/multi-walled carbon nanotube modified glassy carbon electrode for determination of amlodipine in human biological fluids. J Solid State Electrochem 18:985-992. https://doi.org/10.1007/s10008-013-2345-3

20. Ojani R, Alinezhad A, Abedi Z (2013) A highly sensitive electrochemical sensor for simultaneous detection of uric acid, xanthine and hypoxanthine based on poly(L-methionine) modified glassy carbon electrode. Sens Actuators B Chem 188:621-630. https://doi.org/10.1016/j.snb.2013.07.015

21. Jiokeng SLZ, Tonle IK, Walcarius A (2019) Amino-attapulgite/ mesoporous silica composite films generated by electroassisted self-assembly for the voltammetric determination of diclofenac. Sens Actuators B Chem 287:296-305. https://doi. org/10.1016/j.snb.2019.02.038

22. Saadaoui M, Fernandez I, Luna G, Diez P, Campuzano S, Raouafi N, Sanchez A, Pingarron JM, Villalonga R (2016) Label-free electrochemical genosensor based on mesoporous silica thin film. Anal Bioanal Chem 408:7321-7327. https://doi. org/10.1007/s00216-016-9608-7

23. Hu S, Wang Y, Wang X, Xu L, Xiang J, Sun W (2012) Electrochemical detection of hydroquinone with a gold nanoparticle and graphene-modified carbon ionic liquid electrode. Sens Actuators B Chem 168:27-33. https://doi.org/10.1016/j. snb.2011.12.108

24. Tajeu KY, Ymele E, Jiokeng SLZ, Tonle IK (2019) Electrochemical sensor for caffeine based on a glassy carbon electrode modified with an attapulgite/nafion film. Electroanalysis 31(2):350-356. https://doi.org/10.1002/elan.201800621

25. Ymélé E, Jiokeng SLZ, Tchieno FMM, Tonle IK (2017) Nanohybrid materials from amine functionalization of sepiolite: preparation, characterization and application as electrode modifiers for the electroanalytical detection of heavy metal ions. Adv Mater Sci 2(4):1-8. https://doi.org/10.15761/ams.1000133

26. Jiokeng SLZ, Dongmo LM, Ymélé E, Ngameni E, Tonlé IK (2017) Sensitive stripping voltammetry detection of $\mathrm{Pb}(\mathrm{II})$ at a glassy carbon electrode modified with an amino-functionalized attapulgite. Sens Actuators B Chem 242:1027-1034. https://doi. org/10.1016/j.snb.2016.09.150 
27. Tchieno FMM, Sonfack LG, Ymélé E, Ngameni E, Tonle IK (2017) Electroanalytical application of amine-grafted attapulgite to the sensitive quantification of the bioactive compound mangiferin. Electroanalysis 29(2):529-537. https://doi.org/10.1002/ elan.201600381

28. Kamgaing T, Tonle IK, Emanbou YF (2013) Electrochemical analysis of hydroquinone using glassy carbon electrode coated with a clay film amended by L-cysteine. Eurasian J Anal Chem $8(2): 64-77$

29. Shan D, Mousty C, Cosnier S, Mu SL (2009) A composite poly azure B-clay-enzyme sensor for the mediated electrochemical determination of phenols. J Electroanal Chem 537:103-109. https://doi.org/10.1016/S0022-0728(02)01255-x

30. Zen JM, Chen FJ (1998) An ultrasensitive voltammetric method for dopamine and catechol detection using clay-modified electrodes. Electroanalysis 10:12-15. https://doi.org/10.1002/ (sici)1521-4109(199801)

31. Navratilova Z, Kula P (2003) Clay modified electrodes: present applications and prospects. Electroanalysis 15:837-846. https:// doi.org/10.1002/elan.200390103

32. Bailey GW (1980) Structure of layer silicates. In: Brindley GW, Brown G (eds) Crystal structure of layer silicates and their X-ray identification. Mineralogical Society, London, pp 1-123

33. Tonlé IK, Ngameni E, Walcarius A (2004) From clay to organoclay-film modified electrodes: tuning charge selectivity in ion exchange voltammetry. Electrochim Acta 49:3435-3443. https ://doi.org/10.1016/j.electacta.2004.03.012

34. Tcheumi HL, Tonle IK, Ngameni E, Walcarius A (2010) Electrochemical analysis of methyl parathion pesticide by a gemini surfactant-intercalated clay-modified electrode. Talanta 81:972979. https://doi.org/10.1016/j.talanta.2010.01.049

35. Dias Filho NL, do Carmo DR, Gessner F, Rosa AH (2005) Preparation of a clay-modified carbon paste electrode based on 2-thiazoline-2-thiol-hexadecyl ammonium sorption for sensitive determination of mercury. Anal Sci 21:1309-1316. https://doi. org/10.2116/analsci.21.1309

36. Beltagia AM, Ghoneim EM, Ghoneim MM (2011) Simultaneous determination of cadmium(II), lead(II), copper(II) and mercury(II) by square-wave anodic stripping voltammetry at a montmorilIonite-calcium modified carbon paste electrode. Int J Environ Anal Chem 91(1):17-32. https://doi.org/10.1080/0306731090 2962577

37. Lesch A, Salazar FC, Bassetto VC, Amstutz V, Girault HH (2015) Inkjet printing meets electrochemical energy conversion. Chimia 69:284-289. https://doi.org/10.2533/chimia.2015.284

38. Dong S, Wang Z, Asif M, Wang H, Yu Y, Hu Y, Liu H, Xiao F (2017) Inkjet printing synthesis of sandwiched structured ionic liquidcarbon nanotube-graphene film: toward disposable electrode for sensitive heavy metal detection in environmental water samples. Ind Eng Chem Res 56:1696-1703. https://doi.org/10.1021/ acs.iecr.6b04251

39. Lesch A, Salazar FC, Prudent M, Delobel J, Rastgar S, Lion N, Tissot JD, Tacchini P, Girault HH (2014) Large scale inkjet-printing of carbon nanotubes electrodes for antioxidant assays in blood bags. J Electroanal Chem 717-718:61-68. https://doi. org/10.1016/j.jelechem.2013.12.027

40. Yang Z, Xiao J, Wan JY, Liu ZG, Cao TT, Zhang WJ, Wang HX (2015) Graphene oxide/carbon dot composite: a new photoelectrode material for photocurrent response enhancement. Phys Chem Chem Phys 17:32283-32288. https://doi.org/10.1039/c5cp0 $5616 \mathrm{k}$

41. Zhu YW, Murali S, Cai WW, Li XS, Suk JW, Potts JR, Ruoff RS (2010) Graphene and graphene oxide: synthesis, properties and applications. Adv Mater 22:3906-3924. https://doi.org/10.1002/ adma.201001068

\section{SN Applied Sciences}

42. Xing H, Xu J, Zhu X, Duan X, Lu L, Wang W, Zhang Y, Yang T (2016) Highly sensitive simultaneous determination of cadmium(II), lead(II), copper(II), and mercury(II) ions on N-doped grapheme modified electrode. J Electroanal Chem 760:52-58. https://doi. org/10.1016/j.jelechem.2015.11.043

43. Moya A, Gabriel G, Villa R, del Campo FJ (2017) Inkjet-printed electrochemical sensors. Sens Biosens 3:29-39. https://doi. org/10.1016/j.coelec.2017.05.003

44. Zuo Y, Xu J, Xing H, Duan X, Lu L, Ye G, Jia H, Yu Y (2018) Simple and green synthesis of piperazine grafted reduced graphene oxide and its application for the detection of $\mathrm{Hg}(\mathrm{II})$. Nanotechnology 29:165502-1-165508. https://doi.org/10.1088/13616528/aaaf4a

45. Xing H, Xu J, Zhu X, Duan X, Lu L, Zuo Y, Zhang Y, Wang W (2016) A new electrochemical sensor based on carboimidazole grafted reduced graphene oxide for simultaneous detection of $\mathrm{Hg}^{2+}$ and $\mathrm{Pb}^{2+}$. J Electroanal Chem 782:250-255. https://doi.org/10.1016/j. jelechem.2016.10.043

46. Zuo $Y, X u$ J, Jiang $F$, Duan $X$, Lu L, Xing $H$, Yang $T$, Zhang $Y$, Ye G, $\mathrm{Yu} Y$ (2017) Voltammetric sensing of $\mathrm{Pb}$ (II) using a glassy carbon electrode modified with composites consisting of $\mathrm{Co}_{3} \mathrm{O}_{4}$ nanoparticles, reduced graphene oxide and chitosan. J Electroanal Chem 801:146-152. https://doi.org/10.1016/j.jelec hem.2017.07.046

47. Zuo $Y, X u$ J, Zhu X, Duan X, Lu L, Gao Y, Xing H, Yang T, Ye G, Yu Y (2016) Poly(3,4-ethylenedioxythiophene) nanorods/graphene oxide nanocomposite as a new electrode material for the selective electrochemical detection of mercury (II). Synth Met 220:14-19. https://doi.org/10.1016/j.synthmet.2016.05.022

48. Zuo Y, Xu J, Zhu X, Duan X, Lu L, Yu Y (2019) Graphene-derived nanomaterials as recognition elements for electrochemical determination of heavy metal ions: a review. Microchim Acta 186:1-17. https://doi.org/10.1007/s00604-019-3248-5

49. Zhaohui L, Po-Hsiang C, Jiin-Shuh J, Wei-Teh J, Chih-Jen W (2010) Interaction between tetracycline and smectite in aqueous solution. J Colloid Interf Sci 341:311-319. https://doi.org/10.1016/j. jcis.2009.09.054

50. Cravero F, Keith KS, Murray HH, Toth T (2000) A white bentonite from San Juan Province, Argentina-geology and potential industrial applications. Appl Clay Sci 16:31-43. https://doi. org/10.1016/S0169-1317(99)00045-9

51. Ma K, Pierre AC (1999) Colloidal behavior of montmorillonite in the presence of $\mathrm{Fe}^{3+}$ ions. Colloids Surf A Physicochem Eng Asp 155:359-372. https://doi.org/10.1016/S0927-7757(99)00032-1

52. Tonle IK, Ngameni E, Walcarius A (2005) Preconcentration and voltammetric analysis of mercury(II) at a carbon paste electrode modified with natural smectite-type clays grafted with organic chelating groups. Sens Actuators B Chem 110:195-203. https:// doi.org/10.1016/j.snb.2005.01.027

53. Tonle IK, Ngameni E, Walcarius A (2004) From clay- to organoclay-film modified electrodes: tuning charge selectivity in ion exchange voltammetry. Electrochim Acta 49:3435-3443. https ://doi.org/10.1016/j.electacta.2004.03.012

54. Liqiang L, Xia W, Yaping D, Qiuxia L, Jianbo J, Dongmei D (2010) Voltammetric determination of $\mathrm{Pb}^{2+}$ and $\mathrm{Cd}^{2+}$ with montmorillonite-bismuth-carbon electrodes. Appl Clay Sci 50:154-157. https://doi.org/10.1016/j.clay.2010.06.024

55. Cao L, Jia J, Wang Z (2008) Sensitive determination of Cd and $\mathrm{Pb}$ by differential pulse stripping voltammetry with in situ bismuth-modified zeolite doped carbon paste electrodes. Electrochim Acta 53:2177-2182. https://doi.org/10.1016/j.elect acta.2007.09.024

56. Tonle IK, Ngameni E, Tchieno FMM, Walcarius A (2015) Organoclay-modified electrodes: preparation, characterization and recent electroanalytical applications. J Solid State Electrochem 19:1949-1973. https://doi.org/10.1007/s10008-014-2728-0 
57. Yuan S, Chen W, Hu S (2004) Simultaneous determination of cadmium(II) and lead(II) with clay nanoparticles and anthraquinone complexly modified glassy carbon electrode. Talanta 64:922-928. https://doi.org/10.1016/j.talanta.2004.04.008

58. Wang J, Lu J, Hocevar SB, Farias PAM, Ogorevc B (2000) Bismuthcoated carbon electrodes for anodic stripping voltammetry. Anal Chem 72:3218-3222. https://doi.org/10.1021/ac000108x

59. Wang J (2005) Stripping analysis at bismuth electrodes: a review. Electroanalysis 17:1341-1346. https://doi.org/10.1002/ elan.200403270

60. Lee G-J, Kim CK, Lee MK, Rhee CK (2010) Advanced use of nanobismuth/nafion electrode for trace analyses of zinc, cadmium and lead. J Electrochem Soc 157:J241-J244. https://doi, org/10.1149/1.3413998

61. Lee G-J, Kim CK, Lee MK, Rhee CK (2010) Simultaneous voltammetric determination of $\mathrm{Zn}, \mathrm{Cd}$ and $\mathrm{Pb}$ at bismuth nanopowder electrodes with various particle size distributions. Electroanalysis 22:530-535. https://doi.org/10.1002/elan.200900356

62. Lee GJ, Lee HM, Rhee CK (2007) Bismuth nano-powder electrode for trace analysis of heavy metals using anodic stripping voltammetry. Electrochem Commun 9:2514-2518. https://doi. org/10.1016/j.elecom.2007.07.030

63. Lezi N, Economou A, Dimovasilis PA, Trikalitis PN, Prodromidis MI (2012) Disposable screen-printed sensors modified with bismuth precursor compounds for the rapid voltammetric screening of trace $\mathrm{Pb}$ (II) and $\mathrm{Cd}(\mathrm{II})$. Anal Chim Acta 728:1-8. https://doi. org/10.1016/j.aca.2012.03.036

64. Hormigos RM, Gismera J, Procopio JR, Sevilla T (2016) Disposable screen-printed electrode modified with bismuth-PSS composites as a high sensitive sensor for cadmium and lead determination. J Electroanal Chem 767:114-122. https://doi. org/10.1016/j.jelechem.2016.02.025

65. Hwang GH, Han WK, Park JS, Kang SG (2008) An electrochemical sensor based on the reduction of screen-printed bismuth oxide for the determination of trace lead and cadmium. Sens Actuators B Chem 135:309-316. https://doi.org/10.1016/j. snb.2008.08.039

66. Xu H, Zeng L, Xing S, Xian Y, Shi G, Jin L (2008) Ultrasensitive voltammetric detection of trace lead(II) and cadmium(II) using MWCNTs-nafion/bismuth composite electrodes. Electroanalysis 20:2655-2662. https://doi.org/10.1002/elan.200804367

67. Kefala G, Economou A, Voulgaropoulos A (2004) A study of nafion-coated bismuth-film electrodes for the determination of trace metals by anodic stripping voltammetry. Analyst 129:1082-1090. https://doi.org/10.1039/B404978K

68. Wu Y, Li NB, Luo HQ (2008) Simultaneous measurement of Pb, Cd and $\mathrm{Zn}$ using differential pulse anodic stripping voltammetry at a bismuth/poly(p-aminobenzene sulfonic acid) film electrode. Sens Actuators B Chem 133:677-681. https://doi.org/10.1016/j. snb.2008.04.001

69. Zhu L, Xu L, Huang B, Jia N, Tan L, Yao S (2014) Simultaneous determination of $\mathrm{Cd}(\mathrm{II})$ and $\mathrm{Pb}$ (II) using square wave anodic stripping voltammetry at a gold nanoparticle-graphenecysteine composite modified bismuth film electrode. Electrochim Acta 115:471-477. https://doi.org/10.1016/j.elect acta.2013.10.209

Publisher's Note Springer Nature remains neutral with regard to jurisdictional claims in published maps and institutional affiliations. 